\title{
Using Servqual to Examine Service Quality in the Classroom: Analyses of Undergraduate and Executive Education Operations Management Courses
}

\author{
Cyril Foropon ${ }^{1}$, Ruth Seiple ${ }^{2} \&$ Laoucine Kerbache ${ }^{3}$ \\ ${ }^{1}$ Asper School of Business, University of Manitoba, Winnipeg, Canada \\ ${ }^{2}$ Lindner College of Business, University of Cincinnati, Cincinnati, United States \\ ${ }^{3}$ HEC Paris in Qatar, Doha, Qatar \\ Correspondence: Cyril Foropon, Asper School of Business, University of Manitoba, Winnipeg, Manitoba, R3T \\ 5V4, Canada. E-mail: cyril.foropon@ad.umanitoba.ca
}

Received: June 4, 2013

Accepted: August 27, 2013

Online Published: September 22, 2013

doi:10.5539/ijbm.v8n20p105

URL: http://dx.doi.org/10.5539/ijbm.v8n20p105

\begin{abstract}
This article examines service quality provided in the classroom, by applying the Servqual instrument in two operations management (OM) courses located at the two extremes of the higher education spectrum. The first Servqual gap analysis assessed an OM undergraduate course (at the low end of the spectrum), whereas the second Servqual gap analysis appraised an OM executive education course (at the highest end of the spectrum). This paper also reviews the theoretical background of service quality in higher education, and associated assessment methods identified in the literature. Findings indicate that the use of Servqual results could lead to improving the performance of service quality dimensions in the classroom at the undergraduate level, and expectations of undergraduate students and executive education participants could be exceeded on multiple service quality dimensions such as reliability, responsiveness, and tangibles.
\end{abstract}

Keywords: service quality, servqual, higher education institutions

\section{Introduction}

The first studies focusing on service quality in higher education were published during the mid-1990s (Ford, Joseph, \& Joseph, 1999; Harrop \& Douglas, 1996; Harvey \& Knight, 1996; Shank, 1995). Since then, service quality in higher education has attracted more and more attention from both academics and practitioners (Barnes, 2007), and higher education institutions (HEIs) have started to look for ways to improve the delivery of higher education (Nedwek \& Neal, 1994).

Since the mid-1990s, a large variety of assessment methods have been used to appraise service quality in higher education, namely: student evaluations, importance-performance analysis (IPA), Servperf analysis, gap analysis, and Servqual gap analysis. The Servqual instrument (Parasuraman, Berry, \& Zeithaml, 1991, 1994; Parasuraman, Zeithaml, \& Berry, 1988) - widely recognized in the service sector as a multi-item scale developed to assess customer perceptions of service quality - has been used to assess service quality in higher education at the undergraduate level (O'Neill, 2003; Pariseau \& McDaniel, 1997; Stodnick \& Rogers, 2008) as well as at the graduate and postgraduate levels (Barnes, 2007; Markovic, 2006; Shekarchizadeh, Rasli, \& Hon-Tat, 2011; Smith, Smith, \& Clark, 2007).

Stodnick and Rogers's (2008) study applied the Servqual instrument to measure student perceptions of service quality in a classroom setting, and the results demonstrated that a customer-centric quality scale such as Servqual could be applied in a classroom setting. Our paper uses the innovative Servqual approach to examine the classroom service quality in two operations management $(\mathrm{OM})$ classroom settings located at the extremes of the higher education spectrum: an undergraduate course and an executive education course. Ours is the first Servqual study to assess OM higher education courses; in this paper, we use the Servqual approach to examine the service quality of two distinct OM higher education courses. Specifically, the first Servqual gap analysis aims at analyzing the extent to which the use of Servqual results improves the service quality in the classroom at the undergraduate level, whereas the second Servqual gap analysis aims at measuring the service quality in the classroom at the executive education level. The next section of this paper presents the theoretical background of 
service quality in higher education. We then present our data collection method, results and discussion, and conclusion, as well as suggestions for further research.

\section{Theoretical Background of Service Quality in Higher Education}

This section starts by outlining the historical trend in studying service quality in the higher education sector, followed by an overview of service quality assessment methods used in previous studies, and ending with a synthesis of previous studies using the Servqual instrument.

\subsection{Service Quality within the Higher Education Sector}

Several studies have explored aspects of service quality relating to the teaching and learning factors, as well as the environmental attributes, that influence higher education (Angell, Heffernan, \& Megicks, 2008; Barnes, 2007; Cuthbert, 1996; Ford et al., 1999; Harrop \& Douglas, 1996; Harvey \& Knight, 1996; Lau, 2003; Narasimhan, 1997; Oldfield \& Baron, 2000; Qureshi, Shaukat, \& Hijazi, 2010; Shank, 1995).

First, HEIs need to better understand the nature and quality of service, for a number of reasons that have been suggested in the literature. Indeed, Cuthbert (1996) found that word-of-mouth recommendations play a large role in students' decision to choose a university, and that both university quality assurance and independent assessment evaluators place heavy emphasis on the student experience as an assessment criterion. Ford et al. (1999) pointed to a high competitive intensity surrounding business-related courses, and a reduction in state funding and greater consumer demands. Oldfield and Baron (2000) stated that creating a competitive advantage has become a driving force for HEIs. Similarly, Lau (2003) maintained that student retention has become a challenging problem for the academic community, and that effective measures for student retention must be implemented in order to increase the retention of qualified students at HEIs. Consequently, a growing number of institutions and academics have grappled with quality issues and have undertaken research with the aim of addressing some of the key concerns (Lau, 2003; Oldfield \& Baron, 2000). In the mid-1990s, a variety of quality initiatives were undertaken in the higher education sector (Avdjieva \& Wilson, 2002) by HEIs inspired by the success of such initiatives in large corporations in other sectors (Kanji \& Tambi, 1999).

Second, the higher education sector has placed greater emphasis on meeting the expectations and needs of its participating customers - that is, existing students - over the last decade (Cheng \& Tam, 1997). Other groups of actors affecting the education process include potential students, employees, employers, government, and industry (Kanji \& Tambi, 1999). The climate in higher education suggests that students could be seen as primary customers of HEIs (Hill, 1995; Thorne \& Cuthbert, 1996; Sander, Stevenson, King, \& Coates, 2000). According to Sunanto, Taufiqurrahman, and Pangemanan, (2007), HEIs should view students as their primary clients and seek to maximize their satisfaction, not only with curriculum and administrative processes but also in terms of educational services offered. Similarly, Qureshi et al. (2010) based their work on the assumption that students are considered "service recipients or customers" while teachers play a vital role as "service providers."

Third, several factors influencing performance and business excellence of HEIs have been identified since the mid-1990s. Adee (1997) suggested several "university characteristics" that may be useful in explaining a university's perceived quality among students: an emphasis on competent teaching, the availability of staff for student consultation, and library services, computer facilities, recreational activities, class sizes, level and difficulty of subject content, and student workload. Kanji \& Tambi (1999) identified nine total quality management (TQM) critical success factors influencing performance and business excellence of UK HEIs; satisfying external customers such as students was the third most critical factor (after leadership and continuous improvement). Ford et al. (1999) analyzed attributes contributing to an excellent university; their findings indicated that US and New Zealand universities should focus their efforts on reputation, career opportunities, program issues, physical aspects, and location, in that order. Ford et al. warned that blanket strategies may not be applicable globally, as different cultures could have different service quality needs. Finally, Oldfield and Baron (2000) conducted an empirical study of business and management students in the UK; their findings revealed three dimensions of perceived service quality in higher education: "requisite elements" (essential to enable students to fulfill their studies), "acceptable elements" (desirable but not essential), and "functional elements" (practical or utilitarian).

Fourth, the service quality delivered at the high end of the higher education spectrum has been analyzed by relatively few studies (Angell et al., 2008; Barnes, 2007; Lampley, 2001; Shekarchizadeh et al., 2011). Barnes (2007) and Angell et al. (2008) observed that although undergraduates' perception of service quality had been extensively measured, very little had been concluded with regard to postgraduates. In their own studies, these researchers found that postgraduate students' perceptions of the service are falling short of their expectations on all statements. For example, Barnes (2007) conducted research with postgraduate Chinese international students at 
a leading business and management school in the UK, and found significant differences between students' perceptions and expectations of service on all statements. Barnes also discovered that the reliability dimension appeared to be the most important dimension, followed by responsiveness, tangibles, empathy, and assurance. Angell et al.'s (2008) findings suggested that the "academic" and "industry links" aspects of service quality are the most critical to postgraduates. Lampley (2001) also undertook research with doctoral students, and indicated that attentive listening is required among faculty so that students are fully heard and an appropriate service is provided. Shekarchizadeh et al. (2011) focused on international postgraduate students studying in selected Malaysian universities, and found that all items were perceived as significantly negative compared to expectations. Service quality of executive education programs provided by HEIs has not yet been assessed, and one objective of this study is to use the Servqual instrument to measure the quality of service of one course located in this particular higher education niche.

\subsection{Measuring Service Quality in Higher Education}

Multiple assessment methods have been used to assess service quality in higher education. These include student evaluations, importance-performance analysis (IPA), Servperf analysis, gap analysis, and Servqual gap analysis. Two studies (Aldridge \& Rowley, 1998; Rowley, 1997) used student evaluations to assess service quality. Angell et al. (2008) concluded that IPA is an appropriate tool for measuring service quality in postgraduate education. The IPA framework is best described as "an absolute measure of customer perception" (Wright \& O'Neill, 2002, p. 26) that seeks to identify the underlying "importance" given to service attributes. Cronin and Taylor (1994) proposed another assessment approach called Servperf analysis, which evaluates service quality on the basis of performance only. Recently, Bayraktaroglu and Atrek's (2010) results showed the goodness of fit of the Servperf analysis in higher education services.

Gap analysis has been used in several studies in higher education contexts. These studies were influenced by the work of Parasuraman and colleagues (Parasuraman et al., 1991, 1994; Parasuraman et al., 1988) who created and developed the Servqual gap analysis to measure a service quality construct having five dimensions: tangibles, reliability, responsiveness, assurance, and empathy. Research by Hill (1995) suggested a "mismatch" between students' expectations and perceived quality. Using a framework developed to investigate a small sample of accounting undergraduates in the UK, Hill found negative results (performance minus expectations; P - E) concerning several academic service factors (i.e., course content, teaching quality, teaching methods, personal contact with academic staff, feedback, and student involvement with the curriculum). Long, Tricker, Rangecroft, and Gilroy (1999) used gap analysis to compare what students "look for" (expect) and what they "experience" in distance education courses. Sander et al. (2000) examined undergraduates' expectations and preferences in teaching, learning, and assessment. Lampley (2001) provided another gap analysis, which considered responsiveness/caring, records/paperwork, university services, accessibility/safety, knowledge/scheduling, facilities/equipment, and public relations to measure expectations and perceptions among doctoral students in six US universities. LaBay and Comm (2003), in a sample of undergraduate and distance learning students, evaluated students' expectations and perceptions concerning their tutor. Kong and Muthusamy (2011) used a 37-item questionnaire developed from Gronroos's perceived service quality model, to measure students' perceptions of service quality in a local private higher education institution; service gaps were then calculated from the differences between perceptions of the services received and their respective expectations.

\subsection{Servqual Gap Analysis in Higher Education}

The Servqual gap analysis is a disconfirmation approach (Bayraktaroglu \& Atrek, 2010). The confirmation/disconfirmation approach views customer satisfaction judgments as the result of the consumers' perception of the gap between their perceptions of performance and their prior expectations, and allows service providers to identify service gaps (Parasuraman et al., 1994). Disconfirmation is negative when expectations exceed service performance, and positive when performance exceeds expectations. The gap theory suggests that perception of service quality is driven by the difference between consumers' expectations about the performance of a general class of service providers and their assessments of the actual performance of a specific provider within that class (Shekarchizadeh et al., 2011).

Perceived service quality is a consequence of consumer satisfaction (Adee, 1997), and an important implication for higher education is that all service providers should be managed to enhance student satisfaction. This in turn would enhance perceived service quality. Servqual is recognized as a tried and tested operational instrument that has been successfully applied in various different contexts (Buttle, 1996). Its strengths more than outweigh any deficiencies, and the results can be presented in a format useful for targeting specific service improvements (O'Neill \& Palmer, 2001). Parasuraman et al.'s (1988) findings indicated that of the five key attributes of service 
quality addressed by their Servqual analysis (reliability, tangibles, responsiveness, assurance, and empathy), reliability is largely based on service outcomes, whereas the four other service quality dimensions are more concerned with service processes. Their research also showed that meeting customer expectations is achieved through reliability (service outcomes), whereas exceeding customer expectations is largely achieved through the four remaining attributes (service processes). Stodnick and Rogers (2008) applied the Servqual instrument to the classroom environment, and their findings showed that the Servqual scale exhibits both reliability and validity. Similarly, Barnes's (2007) findings demonstrated that the Servqual instrument is a useful tool for measuring service quality in higher education, and is applicable as a research tool for measuring postgraduate students' perceptions.

Despite the proven success of the Servqual framework in other industries (Barnes, 2007), relatively few studies in higher education have adopted this approach. Initially, a pioneering study in two private business schools in the US (Pariseau \& McDaniel, 1997) used the Servqual framework to draw comparisons between faculty members and undergraduate students regarding their expectations and perceptions of professors. Several dimensions proved to be statistically significant contributors toward perceptions of overall quality provided by instructors. Then, using a modified Servqual scale, O'Neill (2003) undertook a longitudinal study on a sample of undergraduate students in Western Australia. O'Neill found that perceptions of service quality in higher education appear to go down over time; the findings also confirmed suggestions that rising expectations have the effect of downgrading perceptions of previous service. Later, Markovic (2006) used a modified Servqual scale to assess service quality in tourism higher education, and demonstrated that the Servqual instrument is suitable for use by managers in higher education institutions. Barnes (2007) also used a modified Servqual instrument, to investigate expectations and perceptions of service quality among a sample of postgraduate Chinese students at a leading business school in the UK. Barnes's study demonstrated that the Servqual instrument is suitable for use in the context of Chinese postgraduate students. Smith et al. (2007) used an original Servqual scale to explore service quality in an Information Technology service department in an HEI, and found that service quality gaps were the same for students and academic staff. In that study, Smith et al. showed that reliability was the most important dimension for all customers, and that the greatest improvement in service quality would be achieved through service reliability. More recently, Qureshi et al. (2010) examined service quality in HEIs using the Servqual instrument. Qureshi et al. assessed only reliability and responsiveness, and found a significant relationship between these two service quality dimensions and students' satisfaction. Lastly, the 35 items in the modified Servqual used by Shekarchizadeh et al. (2011) were distributed into five different factors: professionalism, reliability, hospitality, tangibles, and commitment. Disconfirmation was negative for all the items, indicating that international postgraduate students' expectations in Malaysia exceeded perceptions of service quality for every item.

Overall, the literature review indicates that neither the service quality of OM undergraduate courses nor the service quality of executive education courses have yet been measured using the Servqual approach. Our research attempts to bridge this gap by applying the Servqual instrument to the classroom environment of two OM undergraduate and executive education courses.

\section{Method}

Data collection procedures are presented in this section. For the first Servqual gap analysis, data were collected through Servqual questionnaires distributed to undergraduate students registered at the University of Cincinnati (USA). For the second Servqual analysis, questionnaires were sent to postgraduate students registered at HEC Paris (France). Each of the predetermined questions mentioned in the Servqual questionnaire was designed to solicit feedback regarding the service quality dimensions, in order to compare student perceptions and expectations of the service being assessed. Details regarding data collection are disclosed below.

\subsection{Data Collection: OM Undergraduate Course}

Data for the undergraduate program were drawn from an introductory business course at the University of Cincinnati. The course is one of a group of six required courses dubbed "the junior core" in the College of Business. The course is taught using a traditional large lecture environment, averaging 200 students during a 10 -week session format, meeting for 1 hour 45 minutes. A rationalization of the five service quality dimensions and their relationship to the first Servqual gap analysis led to the removal of questions relating to reliability and tangibles. Survey questions related to tangibles in the original Servqual questionnaire were designed to evaluate the use of "modern equipment" and how "visually appealing" the environment was. However, these points are beyond the control of the instructor and are uniform across all junior core courses in the business college. As discussed earlier, reliability (i.e., the ability to perform the promised service) is essential for all services, but this first Servqual gap analysis was more interested in the application of process-based measures rather than 
outcome-based measures (Parasuraman et al., 1991), so questions relating to reliability were eliminated. It must be noted, however, that failure in the area of reliability makes any discussion of the remaining four attributes irrelevant. Providers that deliver a service that is not satisfactory in this outcome-based reliability attribute should not even consider exploring customer satisfaction in the four other process-based measures. Their role as service providers will quickly cease if the promised outcome is not fulfilled.

The full version of Servqual comprises 22 questions (each having two parts: one dealing with expectations and one dealing with perceptions). To alleviate survey fatigue and encourage student participation, the questionnaire was reduced to 18 questions covering key attributes of responsiveness, assurance, and empathy; questions related to both tangibles and reliability were eliminated. Also, the original Servqual questionnaire used a banking institution as a model. Following Parasuraman et al.'s (1991) recommendation that the questionnaire be modified for use in assessing service quality in other contexts, the Servqual questions in our first Servqual gap analysis were modified to fit an academic large lecture course. Not all students in a large lecture will seek the professor out personally. Therefore, additional modifications were required, since not all students may have used all aspects of the services available. It was deemed that although the access to the service may not have been exercised, the perception of its availability or what might happen if it were exercised was still useful data in assessing the quality of the service provided. Wording such as "appeared to" or "would be willing to" were meant to invite student perceptions for each key attribute in question. Through observation or inference, a student in a large lecture environment can almost certainly gauge, or will possess personal opinions about, courtesy or promptness beyond personal experience. Those perceptions were applied to the student's assessment of service quality and were necessary in completing a calculation of perceptions minus expectations (P-E).

The survey was delivered during the eighth week of the 10-week quarter through an on-line course tool. Students were anonymous in their responses, and were able to respond within a 3-week window. The course was an introduction to operations management that included the discussion of service quality in the course curriculum. Students were introduced to the five dimensions of service quality several weeks before the modified Servqual tool was launched. The students had not seen the original Servqual instrument. A seven-point Likert scale was used, ranging from 1 (strongly disagree) to 7 (strongly agree). Class sizes averaged 197 students. Data were gathered over five consecutive 10-week quarters, and 425 questionnaires out of 989 were received (i.e., 43\% participation rate). During this time period, the text was changed once, but the course curriculum, instructor, and lecture hall remained the same. Data collection during this first Servqual study allowed us to assess three dimensions of service quality provided in the classroom at the undergraduate level: empathy, assurance, and responsiveness. The assessment of each service quality dimension (i.e., responsiveness, assurance, and empathy) was based on 3 dedicated questions per questionnaire (e.g., 3 questions dealing with responsiveness, 3 questions for assurance, and 3 questions for empathy).

\subsection{Data Collection: OM Executive Education Course}

Data for the graduate program were drawn from an executive education program held at HEC Paris, whose customized executive education program was ranked number one in the world by the Financial Times in 2011. The selected OM course is one among a group of 28 open enrollment programs offered at HEC Executive Education. We used the original Servqual questionnaire to measure the five service quality dimensions (empathy, assurance, responsiveness, reliability, tangibles); however, as suggested by Parasuraman et al. (1991), the wording of the 22 questions was changed to fit the classroom environment. Then, we administered questionnaires to participants at the beginning of the class period to control (reduce) the influence of past experience on formulating expectations (Parasuraman et al., 1994). Each of the 22 registered participants received a Servqual questionnaire, and 20 complete questionnaires were collected (91\% participation rate). This second Servqual gap analysis allows us to measure the service quality in the classroom of an executive education course provided by a leading HEI in this particular higher education niche.

\section{Results and Discussion}

In this section, results from the Servqual gap analyses of one OM undergraduate course and one OM executive education course are successively presented and discussed. 


\subsection{Servqual Gap Analysis of an OM Undergraduate Course}

Table 1. Servqual gap analysis of OM undergraduate services: summary results

\begin{tabular}{|c|c|c|c|c|c|c|c|c|}
\hline t-Test: & & & t-Test: & & & t-Test: & & \\
\hline Two-Sample & & & Two-Sample & & & Two-Sample & & \\
\hline Assuming & & & Assuming & & & Assuming & & \\
\hline Equal & & & Equal & & & Equal & & \\
\hline Variances & & & Variances & & & Variances & & \\
\hline Responsiveness & $\begin{array}{c}\text { Expectation } \\
\text { Variable } 1\end{array}$ & $\begin{array}{c}\text { Perception } \\
\text { Variable } 2 \\
\end{array}$ & Assurance & $\begin{array}{c}\text { Expectation } \\
\text { Variable } 1\end{array}$ & $\begin{array}{c}\text { Perception } \\
\text { Variable } 2 \\
\end{array}$ & Empathy & $\begin{array}{c}\text { Expectation } \\
\text { Variable } 1\end{array}$ & $\begin{array}{c}\text { Perception } \\
\text { Variable } 2 \\
\end{array}$ \\
\hline Mean & 4.01 & 5.45 & Mean & 4.42 & 5.61 & Mean & 3.33 & 4.83 \\
\hline Variance & 2.19 & 1.79 & Variance & 2.44 & 1.78 & Variance & 2.78 & 1.99 \\
\hline Observations & 1274 & 1275 & Observations & 1273 & 1273 & Observations & 1273 & 1273 \\
\hline $\begin{array}{c}\text { Pooled } \\
\text { Variance }\end{array}$ & 1.9870 & & $\begin{array}{c}\text { Pooled } \\
\text { Variance }\end{array}$ & 2.1060 & & $\begin{array}{c}\text { Pooled } \\
\text { Variance }\end{array}$ & 2.3853 & \\
\hline Hypothesized & 0 & & Hypothesized & 0 & & Hypothesized & 0 & \\
\hline Mean & & & Mean & & & Mean & & \\
\hline Difference & & & Difference & & & Difference & & \\
\hline Df & 2547 & & Df & 2544 & & Df & 2544 & \\
\hline $\mathrm{t}$ Stat & -25.7316 & & t Stat & -20.6626 & & $\mathrm{t}$ Stat & -24.5353 & \\
\hline $\begin{array}{l}\mathrm{P}(\mathrm{T}<=\mathrm{t}) \\
\text { one-tail }\end{array}$ & 0.0000 & & $\begin{array}{l}\mathrm{P}(\mathrm{T}<=\mathrm{t}) \\
\text { one-tail }\end{array}$ & 0.0000 & & $\begin{array}{l}\mathrm{P}(\mathrm{T}<=\mathrm{t}) \\
\text { one-tail }\end{array}$ & 0.0000 & \\
\hline $\begin{array}{l}\text { t Critical } \\
\text { one-tail }\end{array}$ & 1.6455 & & $\begin{array}{l}\text { t Critical } \\
\text { one-tail }\end{array}$ & 1.6455 & & $\begin{array}{l}\text { t Critical } \\
\text { one-tail }\end{array}$ & 1.6455 & \\
\hline $\begin{array}{l}\mathrm{P}(\mathrm{T}<=\mathrm{t}) \\
\text { two-tail }\end{array}$ & 0.0000 & & $\begin{array}{l}\mathrm{P}(\mathrm{T}<=\mathrm{t}) \\
\text { two-tail }\end{array}$ & 0.0000 & & $\begin{array}{l}\mathrm{P}(\mathrm{T}<=\mathrm{t}) \\
\text { two-tail }\end{array}$ & 0.0000 & \\
\hline $\begin{array}{l}\text { t Critical } \\
\text { two-tail }\end{array}$ & 1.9609 & & $\begin{array}{l}\text { t Critical } \\
\text { two-tail }\end{array}$ & 1.9609 & & $\begin{array}{l}\text { t Critical } \\
\text { two-tail }\end{array}$ & 1.9609 & \\
\hline
\end{tabular}

First, the results summary in Table 1 indicates that for the undergraduate course, mean differences between perceptions and expectations for all three process-based measures of service quality (i.e., responsiveness, assurance, and empathy) were significantly positive. From a statistical standpoint, paired sample t-tests were undertaken on the perception and expectation mean items in order to identify whether or not statistically significant service quality gaps were apparent. We followed Parasuraman et al.'s (1988) research guidelines, such that meeting expectations is achieved through reliability (service outcomes), whereas exceeding customer expectations is largely achieved through the four remaining attributes (service processes). These significant measured differences on three process-based measures signify that students' expectations regarding OM undergraduate higher education services have been exceeded. Second, results disclosed in Table 1 indicate t-test statistical significance for the mean shift of perceptions to expectations on all three of the variables tested. Across the 1275 student responses (i.e., 3 dedicated questions for the empathy dimension times 425 questionnaires), the empathy dimension showed the highest shift over time, from a 3.33 to a 4.83 mean varying along the 7-point Likert scale. The results still show room for growth toward a score of 7 (strongly agree). The means of the assurance and responsiveness dimensions shifted to 5.44 and 5.60, respectively. If the scores show a strong shift, then evaluation of teaching techniques may help to indicate success factors in such large settings.

Inputs were also collected anonymously from students who participated in the survey. Pooling of those comments seems to indicate teaching techniques in this particular learning environment that may explain student perception scores. For each of the five undergraduate surveys, more than $50 \%$ of the students provided anecdotal input. Students appeared to feel at ease about providing honest feedback. The grouping of comments was then assessed relative to apparent connections to the three measured service quality dimensions. First, concerning the responsiveness dimension, comments from undergraduate students appear to center on two themes: availability and awareness of student needs. Comments about availability, such as "plenty of office hours," "answered emails in 24 hours," "open to questions after class," "always available," and "never seemed too busy," were common. Awareness of student needs was indicated by comments such as "willing to go over material twice," "stops to make sure everyone understood," and "open to questions despite the large lecture format." Second, feedback in 
the area of empathy dealt with inclusiveness and personalization. Several comments discussed being "involved" through in-class dialogue or the use of students in upfront demonstrations. Another comment expressed that "especially for the class to be so large ... [the instructor] makes every student feel involved, which is a feeling you don't get from most other large lecture halls." The use of student first names also emerges, with several students commenting on the instructor's ability to "learn several students by name," that "even in a group of 220 people, it felt like a small class of 25," or that the instructor "made a lecture auditorium feel like a small personal experience." Individualized attention was also mentioned, with several students commenting about one-on-one discussions and individualized attention both during the lecture time and during office hours. Third, regarding the assurance dimension, comments grouped around this attribute dealt with teaching style and application issues. The terms "high energy," "engaging," and "interactive" were commonly noted. Additional input referred to basic public speaking attributes of sound quality and clearly written visuals. Academically, it appeared that students found the course content and instructor's input to be "real world", "applicable to my co-op and internship experience," and "challenging with high expectations."

Further investigation into this learning environment found intentional strategies. The instructor exhibited intentional use of a handful of student names during the sessions. Those named were not just the few students who regularly speak in class, but attempts were made to recall and include students who otherwise would never be recognized in class. Students were at times even given titles such as "Mr. Grocery" for a student who might represent the grocery retail market through a part-time job, or "Miss Accounting" or "Joe Engineer" for a specific student's academic discipline. These names were then inserted into exams and examples throughout the course. The instructor periodically used in-class demonstrations that employed student participation to depict assembly lines or product flow processes. The engagement of a few students was intended to pull in the masses. The instructor also made a conscious effort to consistently hold office hours, refraining from cancelling or sacrificing the set time slot in favor of other duties. Additionally, although the college did not require faculty to communicate with students via email, promptly or otherwise, the instructor had a personal standard of answering student emails in short order. Students appreciated this quick and easy way to communicate with the instructor, and noted that other instructors still tended to rely on office hours or class hours to answer students' questions. Lastly, the instructor's personal background included a work history and consulting experience that spanned several years in industry, and students commented on her ability to provide relevant lecture examples that tied into textbook and academic material. This particular academic institution saw a strong percentage of students who engaged in co-op or internship experiences, and the inclusion of student input during lectures also allowed for what students perceived as relevant and real-world connections.

\subsection{Servqual Gap Analysis of an OM Executive Education Course}

Table 2. Servqual gap analysis of an OM executive education course: summary results

\begin{tabular}{|c|c|c|c|c|c|c|c|}
\hline $\begin{array}{l}\text { Servqual } \\
\text { Dimensions }\end{array}$ & Statement & $\begin{array}{c}\text { Expectation } \\
\text { Score }\end{array}$ & $\begin{array}{c}\text { Perception } \\
\text { Score }\end{array}$ & $\begin{array}{c}\text { Gap } \\
\text { Score }\end{array}$ & $\begin{array}{l}\text { Average for } \\
\text { Dimension }\end{array}$ & $\begin{array}{c}95 \% \\
\text { Confidence } \\
\text { Interval } \\
\end{array}$ & $\begin{array}{c}\mathrm{P} \\
\text { Value }\end{array}$ \\
\hline \multirow{6}{*}{ Tangibles } & 1 & 5.20 & 4.85 & -0.35 & & & \\
\hline & 2 & 5.45 & 4.65 & -0.80 & -0.28 & -0.10 to 0.66 & 0.1480 \\
\hline & 3 & 5.00 & 5.70 & 0.70 & & & \\
\hline & 4 & 5.47 & 4.80 & -0.67 & & & \\
\hline & 5 & 6.05 & 5.05 & -1.00 & & & \\
\hline & 6 & 6.37 & 5.05 & -1.32 & & & \\
\hline \multirow{3}{*}{ Reliability } & 7 & 6.15 & 5.25 & -0.90 & -0.89 & 0.58 to 1.20 & 0.0001 \\
\hline & 8 & 6.20 & 5.30 & -0.90 & & & \\
\hline & 9 & 5.65 & 5.30 & -0.35 & & & \\
\hline \multirow{5}{*}{ Responsiveness } & 10 & 5.90 & 5.30 & -0.60 & & & \\
\hline & 11 & 5.25 & 5.10 & -0.15 & -0.41 & 0.10 to 0.73 & 0.0098 \\
\hline & 12 & 6.20 & 5.55 & -0.65 & & & \\
\hline & 13 & 5.89 & 5.65 & -0.24 & & & \\
\hline & 14 & 6.00 & 6.00 & 0.00 & & & \\
\hline \multirow{3}{*}{ Assurance } & 15 & 6.30 & 5.90 & -0.40 & -0.11 & -0.15 to 0.37 & 0.3876 \\
\hline & 16 & 5.60 & 5.70 & 0.10 & & & \\
\hline & 17 & 6.25 & 6.10 & -0.15 & & & \\
\hline
\end{tabular}




\begin{tabular}{|c|c|c|c|c|c|c|c|}
\hline \multirow{3}{*}{ Empathy } & 18 & 5.85 & 4.95 & -0.90 & & & \multirow{5}{*}{0.0015} \\
\hline & 19 & 4.50 & 5.70 & 1.20 & & & \\
\hline & 20 & 5.90 & 5.00 & -0.90 & -0.48 & & \\
\hline \multirow{2}{*}{ Empathy } & 21 & 6.20 & 5.25 & -0.95 & & & \\
\hline & 22 & 5.95 & 5.10 & -0.85 & & & \\
\hline \multicolumn{8}{|l|}{ Servqual Score } \\
\hline $\begin{array}{l}\text { Servqual } \\
\text { Dimensions }\end{array}$ & & $\begin{array}{c}\text { Average } \\
\text { for } \\
\text { Expectation }\end{array}$ & $\begin{array}{c}\text { Average } \\
\text { for } \\
\text { Perception }\end{array}$ & $\begin{array}{l}\text { Average for } \\
\text { Dimension }\end{array}$ & $\begin{array}{c}\text { Importance } \\
\text { Weights }\end{array}$ & $\begin{array}{r}\text { Wei } \\
\mathrm{Sc}\end{array}$ & hted \\
\hline Tangibles & & 5.28 & 5.00 & -0.28 & 16.75 & -4 & \\
\hline Reliability & & 6.08 & 5.19 & -0.89 & 28.5 & -25 & .47 \\
\hline Responsiveness & & 5.81 & 5.40 & -0.41 & 17.25 & -7 & \\
\hline Assurance & & 6.04 & 5.93 & -0.11 & 23.25 & & \\
\hline Empathy & & 5.68 & 5.20 & -0.48 & 14.25 & & \\
\hline Average weighted Servqual Score & & & & -46.72 & & & \\
\hline
\end{tabular}

In this section, results from our Servqual gap analysis of an executive education course are disclosed and analyzed. Both unweighted and weighted Servqual scores are displayed in Table 2. The results summary in Table 2 indicates that mean differences between perceptions and expectations were statistically significant for three measures of service quality (reliability, responsiveness, and empathy), and not statistically significant for the two other service quality dimensions (assurance and tangibles).

Unweighted Servqual scores lead to four observations concerning the five service quality dimensions under assessment. First, based on the item-by-item analysis, the vast majority of the items were perceived as negative compared to participants' expectations. The greatest discrimination is item 6 ("When a participant has a problem, excellent executive education programs will show a sincere interest in solving it"), with an unweighted gap score of -1.32. Second, it is worth observing that one item was perceived as positive compared to participants' expectations; item 19 ("Excellent executive education programs will have operating hours convenient to all their participants") has an unweighted gap score of +1.20 . Third, based on the construct-by-construct analysis, all of the constructs of perceptions were perceived as negative compared to participants' expectations. The greatest discrimination is for the reliability construct, with a gap score of -0.89 . Fourth, for the overall service quality analysis, perceptions were perceived as negative compared to participants' expectations, with an average unweighted Servqual score of -0.44 . This overall unweighted score is fairly close to the -0.40 gap score recently calculated by Shekarchizadeh et al. (2011), who carried out a Servqual analysis in Malaysian universities.

The weighted Servqual scores disclosed in Table 2 calls for some comment. First, importance weights indicate that executive education participants placed greater emphasis on both reliability and assurance dimensions rather than on the three other service quality dimensions (responsiveness, tangibles, empathy). Second, the weighted Servqual scores allocated to service quality dimensions indicate that the top areas needing improvement are, in order of priority, reliability, responsiveness, and empathy. Participants indicated clearly a large gap score in terms of reliability. Indeed, the reliability weighted Servqual score contributes to more than half of the overall weighted Servqual score. Until now, three Servqual gap analyses in the postgraduate-based research have been published (Angell et al., 2008; Barnes, 2007; Shekarchizadeh et al., 2011). Compared to Angell et al.'s (2007) and Barnes's (2007) results showing that students' perceptions of the service are falling short of their expectations on all statements, this Servqual analysis of an executive education course found that one item was perceived as positive compared to expectations, indicating that expectations from executive education participants could be exceeded on statements of service quality.

\section{Conclusion}

The objective of this research was to use the innovative Servqual approach to examine service quality in the classroom in two distinct OM undergraduate and executive education courses. Findings from our first Servqual gap analysis of the service quality of an OM undergraduate course indicated that undergraduate students' expectations were exceeded on all three Servqual service quality dimensions (responsiveness, assurance, empathy) under assessment. Moreover, this Servqual gap analysis, held over time, pointed out that process-based measures 
of responsiveness, assurance, and empathy can be purposefully influenced, and can also increase student perception of service quality in a large lecture format. The results of our second Servqual gap analysis, which measured the service quality of an OM executive education course, show that participants' perceptions of the course fell short of their expectations on all service quality dimensions. To date, only three Servqual gap analyses in postgraduate-based research have been published (Angell et al., 2008; Barnes, 2007; Shekarchizadeh et al., 2011), and our second Servqual analysis, which deals with an OM executive education course, is the first postgraduate study showing one item being perceived as positive compared to expectations ("Excellent executive education courses will have operating hours convenient to all their participants").

From a pedagogical standpoint, results from this research should encourage instructors to use the Servqual gap approach with a view to examining and improving the service quality in the classroom. The use of a Servqual instrument would promote a systems approach to service quality management, which would enable the faculty member in charge of the course to measure actual performance of service quality dimensions in the classroom, identify potential gaps between expectations and perceptions, and implement and monitor appropriate corrective teaching strategies to bridge service quality gaps, if any. The use of the Servqual gap analysis in the classroom would promote both effective and efficient service quality management. Students have expectations regarding service quality in the classroom, and the use of the Servqual instrument as a teacher's guide would help instructors to both meet and exceed these expectations.

In terms of limitations and extensions of this research, this study examined the use of a Servqual instrument in the classroom within an undergraduate and an executive education course, and findings should not be generalized until confirmed in a variety of settings. Servqual gap analyses should also be replicated in other courses at both undergraduate and executive education levels within other international business schools.

The Service Process Matrix (Schmenner, 1986) has long been used to classify service business according to two key aspects that significantly affect the character of the service delivery process: the labor intensity of the service business process on one hand, and the degree of consumer interaction and service customization on the other. The Service Process Matrix categorizes service businesses into four quadrants (service factories, service shops, mass services, and professional services). It appears that higher education services do not belong to a single quadrant on this matrix. In most cases, academia might prefer to be recognized in the professional services quadrant, with a high degree of interaction and service customization with its customers, that is, students. Nevertheless, despite attempts to keep class size small and personal, economies of scale have often forced higher education services into the mass services quadrant. Also, online or streamed video lecturing reduces costs and helps HEIs to reach the masses. By leveraging capital expenditures and faculty expenses, such delivery mechanisms appear to push portions of higher education services back into the mass services quadrant. Future research may shed light in this area.

Further research is needed in the area of service quality dimensions across the spectrum of higher education services. To what extent do courses at the undergraduate level differ from higher education courses at the executive education level in terms of service quality dimensions? Which service quality dimensions - if any need further emphasis to provide high service quality within each of these two distinct education service businesses? These interrogations appear appropriate, bearing in mind Parasuraman et al.'s (1988) Servqual research, which looked at correlations of the five key attributes of service quality across diverse service businesses and found that the refined Servqual instrument has already identified different key service quality dimensions within each of the four service business quadrants.

Lastly, additional research is required to determine which Servqual key service quality dimensions represent order qualifiers or order winners (Hill, 2000). To survive in a highly competitive environment, HEIs are expected to raise the quality of service they provide. Identification of order qualifiers and order winners would be beneficial both at the undergraduate level (mass services quadrant) and at the graduate/postgraduate level (professional services quadrant).

\section{References}

Adee, A. (1997). Linking student satisfaction and service quality perceptions: the case of university education. European Journal of Marketing, 31(7), 528-540. http://dx.doi.org/10.1108/03090569710176655

Aldridge, S., \& Rowley, J. (1998). Measuring customer satisfaction in higher education. Quality Assurance in Education, 6(4), 197-205. http://dx.doi.org/10.1108/09684889810242182

Angell, R. J., Heffernan, T. W., \& Megicks, P. (2008). Service quality in postgraduate education. Quality Assurance in Education, 16(3), 236-254. http://dx.doi.org/10.1108/09684880810886259 
Avdjieva, M., \& Wilson, W. G. (2002). Exploring the development of quality in higher education. Managing Service Quality, 12(6), 372-383. http://dx.doi.org/10.1108/09604520210451858

Barnes, B. R. (2007). Analysing service quality: the case of post-graduate Chinese students. Total Quality Management \& Business Excellence, 18(3), 313-331. http://dx.doi.org/10.1080/14783360601152558

Bayraktaroglu, G., \& Atrek, B. (2010). Testing the superiority and dimensionality of SERVQUAL vs. SERVPERF in higher education. The Quality Management Journal, 17(1), 47-59.

Buttle, F. (1996). SERVQUAL: review, critique, research agenda. European Journal of Marketing, 30(1), 8-32. http://dx.doi.org/10.1108/03090569610105762

Cheng, Y. C., \& Tam, C. (1997). Multi-models of quality in education. Quality Assurance in Education, 5, $22-31$. http://dx.doi.org/10.1108/09684889710156558

Cronin, J. J., \& Taylor, S. A. (1994). SERVPERF versus SERVQUAL: reconciling performance-based and perceptions minus expectations measurement of service quality. Journal of Marketing, 58(1), 125-131. http://dx.doi.org/10.2307/1252256

Cuthbert, P. (1996a). Managing service quality in HE: is SERVQUAL the answer? Part 1. Managing Service Quality, 6(2), 11-16. http://dx.doi.org/10.1108/09604529610109701

Cuthbert, P. (1996b). Managing service quality in HE: is SERVQUAL the answer? Part 2. Managing Service Quality, 6(3), 31-35. http://dx.doi.org/10.1108/09604529610115858

Ford, J. B., Joseph, M., \& Joseph, B. (1999). Importance-performance analysis as a strategic tool for service marketers: the case of service. Journal of Services Marketing, 13(2/3), 171. http://dx.doi.org/ $10.1108 / 08876049910266068$

Harrop, A., \& Douglas, A. (1996). Do staff and students see eye to eye? New Academic, 5, 8-9.

Harvey, J. (1998). Service quality: a tutorial. Journal of Operations Management, 16, 583-597. http://dx.doi.org.proxy1.lib.umanitoba.ca/10.1016/S0272-6963(97)00026-0

Harvey, L., \& Knight, P. T. (1996). Transforming Higher Education. London: Open University Press.

Hill, F. M. (1995). Managing service quality in higher education: the role of the student as primary consumer. Quality Assurance in Education, 3(3), 10-20. http://dx.doi.org/ 10.1108/09684889510093497

Hill, T. (2000). Manufacturing Strategy: Text and Cases (3rd ed.). Boston: Irwin McGraw-Hill.

Kanji, G. K., \& Tambi, A. M. B. A. (1999). Total quality management in UK higher education institutions. Total Quality Management, 10(1), 129-153. http://dx.doi.org/ 10.1080/0954412998126

Kong, S. M., \& Muthusamy, K. (2011). Using service gaps to classify quality attributes. The TQM Journal, 23(2), 145-163. http://dx.doi.org/ 10.1108/17542731111110212

LaBay, D. G., \& Comm, C. L. (2003). A case study using gap analysis to assess distance learning versus traditional course delivery. The International Journal of Education Management, 17(6/7), 312-317. http://dx.doi.org/ 10.1108/09513540310501003

Lampley, J. H. (2001). Service quality in higher education: expectations versus experiences of doctoral students. College and University, 77(2), 9-14.

Lau, L. K. (2003). Institutional factors affecting student retention. Education, 124(1), 126-136.

Long, P., Tricker, T., Rangecroft, M., \& Gilroy, P. (1999). Measuring the satisfaction gap: education in the market-place. Total Quality Management, 10(4/5), 772-778. http://dx.doi.org/ 10.1080/0954412997794

Luque, R. A., \& Machuca, J. A. D. (2003). An empirical study of POM teaching in Spanish universities (II) Faculty profile, teaching and assessment methods. International Journal of Operations \& Production Management, 23(4), 375-400. http://dx.doi.org/ 10.1108/01443570310467311

Markovic, S. (2006). Students' expectations and perceptions in Croatian tourism and hospitality higher education: SERVQUAL versus UNIQUAL. The South East European Journal of Economics and Business, 1(1), 78-88.

Narasimhan, K. (1997). Improving teaching and learning: perceptions minus expectations gap analysis approach. Training for Quality, 5, 121-125. http://dx.doi.org/10.1108/09684879710173389

Nedwek, B., \& Neal, J. (1994). Performance indicators and regional management tools. Research in Higher Education, 35, 75-104. http://www.jstor.org/stable/40196061 
O'Neill, M. (2003). The influence of time on student perceptions of service quality: the need for longitudinal measures. Journal of Educational Administration, 41(3), 310-324. http://dx.doi.org/10.1108/09578230310474449

O'Neill, M., \& Palmer, A. (2001). Survey timing and consumer perceptions of service quality: an overview of empirical evidence. Managing Service Quality, 11(3), 182-190. http://dx.doi.org/10.1108/09604520110391351

Oldfield, B. M., \& Baron, S. (2000). Student perceptions of service quality in a UK university business and management faculty. Quality Assurance in Education, 82(2), 85-94. http://dx.doi.org/10.1108/09684880010325600

Parasuraman, A., Berry, L. L., \& Zeithaml, V. A. (1991). Refinement and reassessment of the SERVQUAL scale. Journal of Retailing, 67(4), 420-450.

Parasuraman, A., Berry, L. L., \& Zeithaml, V. A. (1994). Reassessment of expectations as a comparison standard in service quality measurement: implications for future research. Journal of Marketing, 58(1), 111-124. http://www.jstor.org/stable/1252255

Parasuraman, A., Zeithaml, V. A., \& Berry, L. L. (1985). A conceptual model of service quality and its implications for future research. Journal of Marketing, 49(4), 41-50. http://dx.doi.org/10.2307/1251430

Parasuraman, A., Zeithaml, V. A., \& Berry, L. L. (1988). SERVQUAL: a multiple-item scale for measuring consumer perceptions of service quality. Journal of Retailing, 64(1), 12-40.

Pariseau, S. E., \& McDaniel, J. R. (1997). Assessing service quality in schools of business. The International Journal of Quality and Reliability Management, 14(3), 204-215. http://dx.doi.org/10.1108/02656719710165455

Qureshi, T. M., Shaukat, M. Z., \& Hijazi, S. T. (2010). Service Quality SERVQUAL model in higher education institutions. What factors are to be considered? Interdisciplinary Journal of Contemporary Research in Business, 2(5), 281-290.

Rowley, J. (1997). Beyond service quality dimensions in higher education and towards a service contract. Quality Assurance in Education, 5(1), 7-15. http://dx.doi.org/10.1108/09684889710156530

Sander, P., Stevenson, K., King, M., \& Coates, D. (2000). University students' expectations of teaching. Studies in Higher Education, 25(3), 309-323. http://dx.doi.org/10.1080/03075070050193433

Schmenner, R. W. (1986). How can service businesses survive and prosper? Sloan Management Review, 27(3), $21-32$.

Shank, M. D., Walker, M., \& Hayes, T. (1995). Understanding professional service expectations: do we know what our students expect in a quality education? Journal of Professional Services Marketing, 13(1), 71-89. http://dx.doi.org/10.1300/J090v13n01_08

Shekarchizadeh, A., Rasli, A., \& Hon-Tat, H. (2011). SERVQUAL in Malaysian universities: perspectives of international students. Business Process Management Journal, 17(1), 67-81. http://dx.doi.org/10.1108/14637151111105580

Smith, G. S., Smith, A., \& Clark, A. (2007). Evaluating service quality in universities: a service department perspective. Quality Assurance in Education, 15(3), 334-351. http://dx.doi.org/10.1108/09684880710773200

Stodnick, M., \& Rogers, P. (2008). Using SERVQUAL to measure the quality of the classroom experience. Decision Sciences Journal of Innovative Education, 6(1), 115-133. http://dx.doi.org/10.1111/j.1540-4609.2007.00162.x

Sunanto, S., Taufiqurrahman, T., \& Pangemanan, R. (2007). An analysis of university service quality gap and student satisfaction in Indonesia. The International Journal of Knowledge, Culture and Change Management, 7(7), 1-10.

Thorne, M., \& Cuthbert, R. (1996). Autonomy, bureaucracy, and competition: the ABC of control in higher education. In Cuthbert, R. (Ed.), Working in Higher Education. Buckingham: Society for Research. Higher Education and Open University Press.

Wright, C., \& O'Neill, M. (2002). Service quality evaluation in the higher education sector: an empirical investigation of students' perceptions. Higher Education Research \& Development, 21(1), 23-39. 
http://dx.doi.org/10.1080/07294360220124639

\section{Copyrights}

Copyright for this article is retained by the author(s), with first publication rights granted to the journal.

This is an open-access article distributed under the terms and conditions of the Creative Commons Attribution license (http://creativecommons.org/licenses/by/3.0/). 